Article

\title{
Analysis of the Impact of the "Sea Toll" Program for Seaports: Resilience and Competitiveness
}

\author{
Lalu Tri Wijaya Nata Kusuma ${ }^{1,2, *(\mathbb{D})}$ and Fu-Shiang Tseng ${ }^{2}$ \\ 1 Department of Industrial Engineering, Faculty of Engineering, Universitas Brawijaya, \\ 65145 Malang, Indonesia \\ 2 Institute of Industrial Management, School of Management, National Central University, \\ Taoyuan City 32001, Taiwan \\ * Correspondence: eltriwijaya@ub.ac.id
}

Received: 31 July 2019; Accepted: 16 August 2019; Published: 19 August 2019

Featured Application: From the findings of this study, we provide the results of an investigation on the application of the "sea toll' system for the archipelagic countries. All stakeholders of the sea port can measure the resilience and competitiveness of the implementation of the "sea toll" system. Furthermore, they can evaluate, improve innovation and, finally, have an impact on the performance of the "sea toll" system.

Abstract: Maritime transportation is one of the most important global activities, especially for archipelagic countries. Inland components that exist within the seaport system, such as port authorities who manage passenger and cruise services even for container unloading and loading areas, have become an important aspect to improve performance and determine competitive strategies for seaports. The importance of this interdependence between ports with passenger services and container seaports led us to investigate the impact of the "sea toll" program on seaport resilience and competitiveness. Although the concept of a "sea toll" was initiated by the US government in 2011, there are only a few, if any, studies or clear standards related to the development of "sea toll" systems in archipelago countries. We conducted an empirical study in Indonesia through an online survey of key stakeholders of seaports, including shipping companies, seaport authorities, commodities companies, and government. The data were analyzed using the analytical hierarchy process technique and the results showed that the "sea toll" had an impact on seaport resilience and competitiveness. For seaport resilience, the "sea toll" had an impact on the strategic alliance. For competitiveness, the "sea toll" had an impact on seaport performance, including ship calling frequency and reliability.

Keywords: "sea toll" program; resilience; competitiveness; AHP

\section{Introduction}

Maritime ports are one of the most important parts of the transportation network. They need to be able to support the transportation of people and goods from one place (hinterland) to another (foreland). The maritime transportation system between regions is highly dependent on the condition of the seaports. Developing ports that provide the best service is one of the most important factors to benefit the economy around the port area, as well as the country itself; and this is especially important in archipelago countries.

Based on World Population Review data [1], the ten largest island countries in the world, in order, are: Indonesia, Japan, Philippines, United Kingdom, Madagascar, Taiwan, Sri Lanka, Cuba, Haiti and 
the Dominican Republic. Indonesia is the country with the largest archipelago in the world, and requires the use of maritime transportation networks to meet the needs of its people across the country.

\subsection{Review of the Maritime Sector of Indonesia}

Based on the data from the Indonesian Ministry of Transportation for 2005-2013, the number of national maritime transport companies increased by about $7.7 \%$ per year, and the provision of the national fleet increased by about $10 \%$ per year. In 2013, the share of ocean freight cargo by national shipping companies had reached $99.7 \%$ [2]. It is clear from these data that the role of the maritime transportation system in Indonesia is of great importance.

However, there are problems with the maritime port operation systems of the transportation network in Indonesia. Based on the annual reports of Pelindo (Indonesian Port Authority Company), the problem in Indonesia in 2012 was logistics costs (and port costs), which were some of the highest in the world (24\% of total GDP of Indonesia or equal to IDR 1.820 trillion per year, compared with Malaysia (15\%), and Japan and the USA (10\%)). According to the Pelindo annual report [3], and our own observations and interviews with representatives of one of the port authorities in Indonesia, the average dwelling time in Indonesian ports is 5-6 days, compared with only one day in Singapore, and that included pre-clearance, custom clearance, and post clearance time. The differences in port operation costs between the regions of Indonesia are also high. By 2023, the logistics market will have become one of the largest industries in the world, but currently ports in Indonesia still have low competitiveness compared with other countries [4]. The reason is that logistics costs are still expensive and dwelling time is still high.

The urgency of providing an efficient national connectivity cost reduction within the national logistics framework has been put on the national agenda. In 2014, the President of Indonesia, Joko Widodo, started to develop a "sea toll" (in Indonesian called Tol laut) that would be used as the connection backbone and make Indonesia the world's maritime axis. Its development requires major changes in the pattern of organization for maritime transportation that will take many years to complete. The changes include provision of port infrastructure, network management, and business systems.

In terms of infrastructure, Indonesia has revitalized and built several ports to support the "sea toll" program. This program aims to improve the resilience and competitiveness of national industries and will have a significant impact on the future of the seaport logistics system in Indonesia.

After running for approximately five years, the implementation of the "sea toll" program needs to be reviewed. This review should include a measure of the impact on the resilience and competitiveness of ports in Indonesia, so we decided to make this the focus of our investigation. Furthermore, analysis of the performance of the "sea toll" program would provide more details about the crucial problems that still frequently occur and the impact on the resilience of the system and the future competitiveness of the ports. It should be noted, the focus for most studies has gradually shifted to port customer service quality and the measurement for seaport competitiveness has changed over time, due to the complex business environment of seaports.

\section{2. "Relative Literature" on the Certain Topic}

The determination of service attributes, especially in terms of logistics costs for maritime transport, has been identified by several studies [5-8]. Unfortunately, the variables used to measure logistics costs and maritime port support systems differ between researchers and there is no standard classification. Although the concept of the "sea toll" was initiated by the US government in 2011, there have been no studies or clear standards related to the development of "sea toll" systems in island countries. Liao and Kao [5] explained that the main requirements of logistics systems were lead-time lists, flexibility, reliability, regularity, completeness, accuracy, fill ratio, organizational accessibility, and complaint handling. 
Lam and Bai [9] developed a model using a quality function deployment (QFD) approach to improve maritime supply chain resilience, taking into account the client needs and maritime considerations. The analysis involved three major shipping lines and a main shipper. The results showed that the three most important resilience measures were contingency plans, monitoring and maintenance, and supply chain relationship management. The study also introduced relatively low visibility and integration between stakeholders in the maritime supply chain. Because Lam and Bai only involved three container-shipment companies in their empirical studies, the results cannot describe the system as a whole, especially when the differences between the environmental and geographical conditions of seaports in Indonesia, and the unique characteristics of each province, are taken into account. In archipelagic areas like Indonesia, implementation of the "sea toll" program is difficult due to the many unique rules of each autonomous region, which regulate a port's operational system based on the interests of each region.

Jeevan et al. [10] investigated whether dry port operations have an impact on the competitiveness of ports, especially container ports. They conducted empirical research with object observations that were the main stakeholders of dry ports in Malaysia through 120 online surveys. Exploratory factor analysis (EFA) is used to analyze data that have been collected. The results of data processing using the EFA approach showed that Malaysia's dry port operations had an impact on port competitiveness. This impact included aspects of improving port performance, increasing variations in services for ports, increasing the proximity of inland ports, increasing volume of port trade, and increasing port capacity. However, the stakeholders involved did not consider the role of local government, even though they have their own authority in making policies and rules of seaport in their area due to the enactment of the regional autonomy law, so there was still a gap if compared with the geographical conditions of the territory of an archipelago such as Indonesia.

Consideration of the literature in this area led us to conclude that we needed the opinion of various stakeholders [11]. The stakeholders we identified were the government (as policymakers), port authorities, shipping/logistics companies, and port service users. Because of the diverse interests of each stakeholder, and the differences in the regulations and policies of the local governments in developing the ports on each island, the analytical hierarchy process (AHP) approach to the analysis and determination of critical variables was particularly suitable. The benefits of the most optimal AHP conceptualization is the possibility of hierarchical modeling of problems, and the possibility of making verbal judgments and confirming consistency [12].

Our study specifically addressed the perceived impact of implementing the "sea toll" program on seaport resilience and competitiveness. By involving more stakeholders at seaports as respondent, especially up to the level of local government that has its own uniqueness of regulation and policies through a comprehensive method approach. We propose that the results of our study could be used as a reference for the development of a "sea toll" in other island countries.

The next section reviews related studies and summarizes the "sea toll" program. Section 3 explains the impact of the "sea toll" program on seaport resilience and competitiveness. Section 4 presents the research methodology, and Section 5 describes the data analysis and discussion. Section 6 discusses the implications of the research and presents the conclusions of the study.

\section{The Indonesian "Sea Toll" Program}

In the national logistic system, the pattern of distribution networks between maritime territories, maritime industries, and ports has undergone many developments to support the economic growth of a region. Seaports in Indonesia are still largely conventional, especially in eastern Indonesia. The ineffectiveness of costs and time operational seaports in some areas of Indonesia also influences the distribution pattern and prices of commodity in Indonesia. Therefore, the implementation of the Indonesian "sea toll" program (to improve the nation's economic growth, especially through optimization of the seaport system) is crucial. 
The Indonesian government, especially President Joko Widodo, has been running the "sea toll" program for several years (see Figure 1). This program is an effort by President Joko Widodo to provide a maritime transport network, together with subsidies and the improvement of port facilities. It is expected to reduce logistics costs and make prices of commodities cheaper. In addition, since the ships are now well scheduled, it is expected that any development can be implemented quickly.

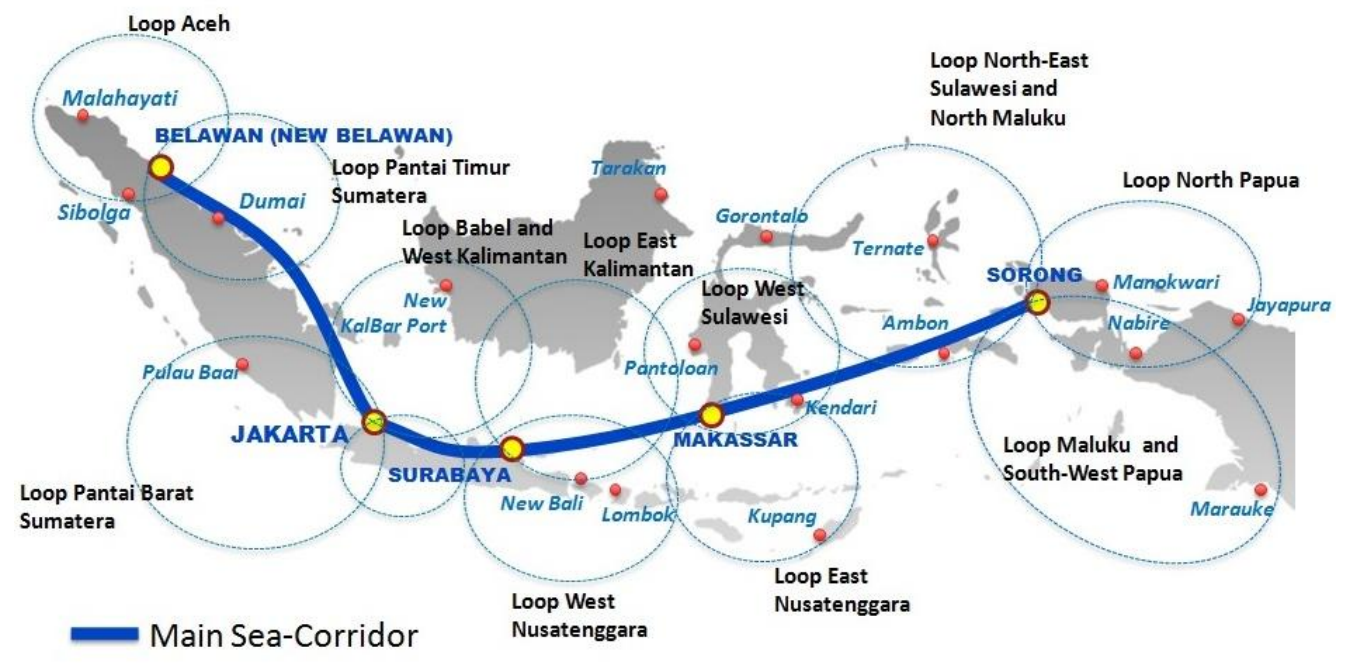

Figure 1. Indonesian Main Sea-Corridor [13].

The first "sea toll" system was introduced by the United States government about eight years ago, based on America's Marine Highway Report to Congress [14], submitted by U.S. Department of Transportation, Maritime Administration. In America's Marine Highway program there are some benefits that have not been fully recognized in current transportation planning and investment decisions. These include assistance for new and existing ships; useful maritime work for the nation in times of peace and national emergency; reduction of and immediate relief from surface transport congestion (especially on routes that provide ground access to urban ports); enhanced, abundant and cost-effective new cargo capacity; reduction of costs in maintenance and repair of roads and bridges; and the creation of a diverse and more resilient transportation system.

In its implementation, the sea transportation system in the territory of Indonesia is divided into two service groups, namely containerization services and passenger and cruise services. Container services are specific to the delivery of commodities or products in large quantities between regions, while the passenger and cruise services service is specifically for passenger transportation services between islands or regions in Indonesia.

\subsection{Sea Toll System for Container Services: Description, Definitions and Supporting Variables Introduction}

The implementation of the "sea toll" program began with the establishment of five main ports in Indonesia as regional hub ports. The role of these five main ports, later as the main transit port for commodity distribution around the remote islands. Data on the distribution of the total cargo for each port are shown in Table 1. Western ports such as Tanjung Priok and Tanjung Perak, still dominate the amount of cargo each year especially Tanjung Priok port because because it is Indonesia's main port in the center of business and government. This shows that port competitiveness is still dominant in the western region, especially Java, while the outer and eastern island regions, in particular, still do not function optimally within the "sea toll" program. 
Table 1. Percentage of total domestic commodity loads in Indonesia's 5 main ports 2015-2017.

\begin{tabular}{cccc}
\hline Main Seaport & $\mathbf{2 0 1 5}$ & $\mathbf{2 0 1 6}$ & $\mathbf{2 0 1 7}$ \\
\hline Belawan Port & $0.70 \%$ & $0.54 \%$ & $0.53 \%$ \\
Tanjung Priok Port & $41.40 \%$ & $43.13 \%$ & $40.32 \%$ \\
Tanjung Perak Port & $16.40 \%$ & $16.75 \%$ & $16.26 \%$ \\
Balikpapan Port & $29 \%$ & $28 \%$ & $32 \%$ \\
Makassar Port & $12.50 \%$ & $11.60 \%$ & $10.61 \%$ \\
\hline
\end{tabular}

Source: BPS [15].

In the element of the sea toll system, especially container services, there are five supporting variables as shown in Figure 2. These variables are related to a reliable port, cargo adequacy transported both from the west to the east of Indonesia and vice versa, Shipping Industry, effective Inland Access and Scheduled routine shipping.

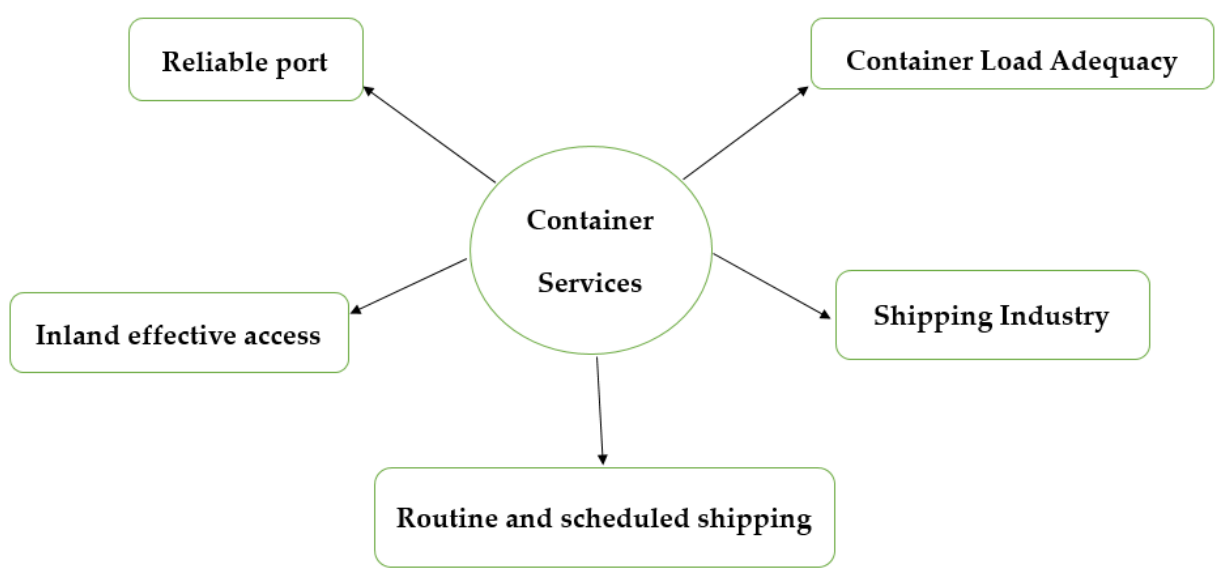

Figure 2. Chart of sea toll elements container services. Source: Indonesian Main Sea-Corridor [13].

Reliable ports are one of the important variables in the container service sea toll system, just as how port authorities and stakeholders involved in carrying out port service systems effectively and efficiently are the key to port performance. What is the percentage of the total capacity installed in the loading/unloading process, the level of productivity, the effectiveness of the administrative/documentation process, the speed of access to data and information systems, water entrance transportation, and of course the effectiveness of other supporting stakeholders into important sub-variables in the level of service reliability port?

While routine and scheduled services, especially related to alternative service routes, the size (size) of the ship and its cargo, rely on the effectiveness of the window system and INAPORT (management information system).

The integration of supporting transportation modes for port access with land areas or islands makes service more effective and efficient. Both from the coast, river, land and pipeline access.

If we look in detail at the variable shipping industry as shown in Figure 3, there will be many supporting sub-variables that are interrelated. So that in the decision making process, there are many variables that need to be taken into consideration in several alternative decisions. 


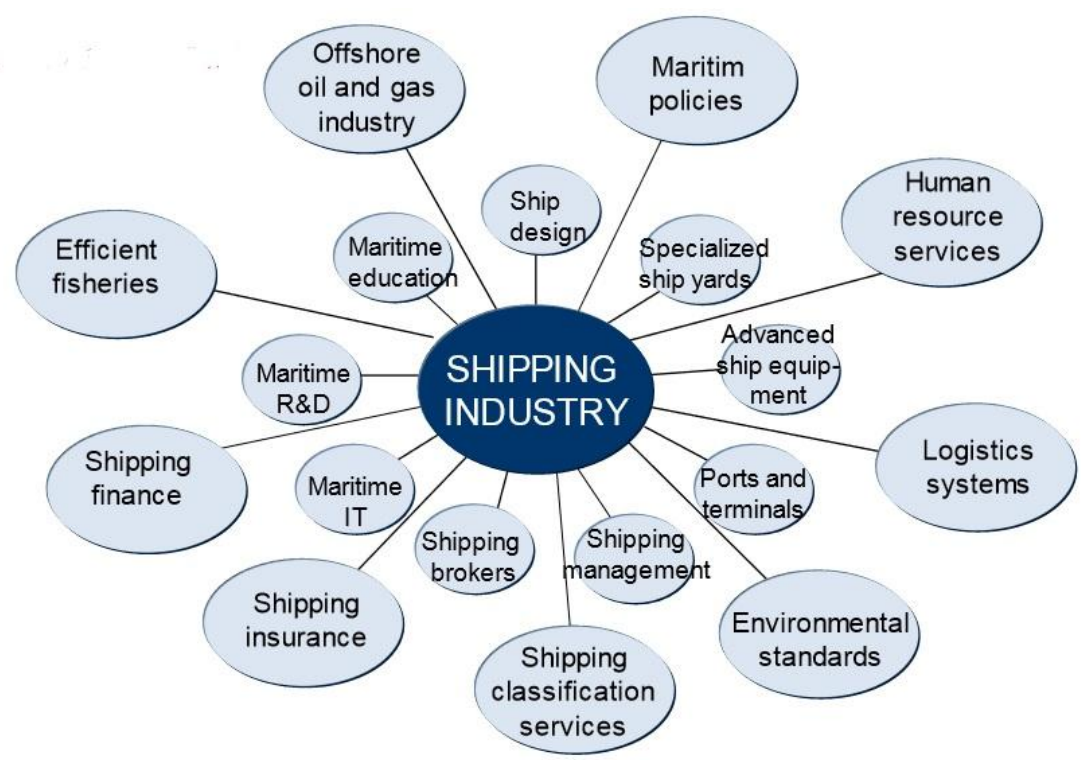

Figure 3. Shipping industry supporting structure. Source: Indonesian Main Sea-Corridor [13].

\subsection{Sea Toll System for Passenger E Cruise Services: Description, Definitions and Supporting} Variables Introduction

The sea toll system also does not only serve the container sector, but inter-island and cruise passenger transportation services are also included in the direction of the system policy. There are four variables included in the passenger and cruise service support system, namely service specialization, commercial/tourist destinations, travel/leisure shipping, and supporting transportation integrations as shown in Figure 4 below.

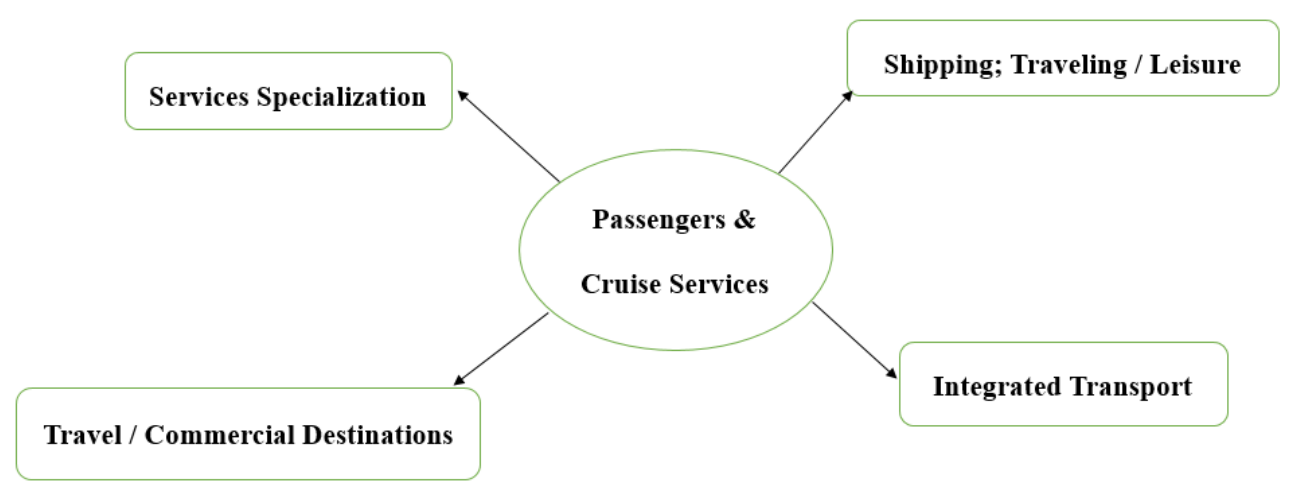

Figure 4. Chart of sea toll elements for passenger services and cruise. Source: Indonesian Main Sea-Corridor [13].

Sea transportation services for passenger and cruise sectors over the last few years have faced significant challenges, both internally and externally. Competition with the air transportation market is the biggest challenge for the island nation, because the large number of low-cost flights between islands makes alternative air transportation more promising for consumers. However, in the concept of sea toll, passenger and cruise services need to slightly change the target market and its service model.

Starting with service specialization, service providers need to group services into several alternative services that consumers can enjoy. Service specialization will distinguish the quality of these services with other transportation services.

Focusing on these services can be seen in other variables, such as services which focuses on the tourism destination sector or commercial demand, then shipping that serves passengers who want to 
travel or leisure. And of course, the transportation service model that is integrated with other modes of transportation on land will greatly help and increase the satisfaction of passengers.

\subsection{Investigation of the Impact of the Implementation of the Sea Toll System on the Development for the Seaport System}

The implementation of a "sea toll" system in an archipelago country has not been addressed clearly in previous studies. Protopapas et al. [16] only addressed the issue of marine highway transportation in relation to toxic inhalation of hazardous materials in the North American region.

In this study, we investigated the impact of the implementation of the "sea toll" system on the competitiveness of seaports. It is clear that the regionalization phase and associated hinterland concepts in each port area between islands, require advanced approaches to port control and a functional focus that exceeds the conventional port perimeter because each province in Indonesia has its own characteristics, especially with regard to its seaport system.

Several previous studies have discussed the development of port systems, at both strategic and operational levels. Liang [6] determined viable solutions for the implementation of knowledge management in a port. The top five solutions were data storage and data mining systems, decision support systems, information and communication infrastructure development, database development for document management, and utilization of groupware and other software.

In developing and enhancing the growth of maritime ports, it should be possible to facilitate the influence of cultural, institutional, and governance factors of the home country, the influence of an economic and competitive environment in the home market, and stakeholder management [7]. Kavaliauskiene [12], using a service quality approach, proposed that logistic service users were conservative and cautious when considering innovations. Nevertheless, they properly understand the importance to meet IT integration and are aware of their shortage of technological adjustments in logistics processes at different stages of customer service. Lee [8] used structural equation models (SEM) to determine some variables for improving port performance such as the SERVQUAL (service quality) model, brand awareness, brand loyalty, and overall value of brand equity.

Fruth and Teuteberg [17] in their research provide a general description of digitalization in the maritime logistics system, what problems are faced, and any potential that can be optimized in the future. The results of this study showed the importance of managing existing potential moreover it can take benefits. However, their research is still in the early stages of review, and there is a lack of theoretical and empirical studies, and identification of incomprehensive definitions for future actions and restructuring.

Taking into account the methodology and research findings of previous studies, we concluded that there were still gaps in the development of the seaport system that needed to be addressed. Through our research in Indonesia as one of archipelagic countries, some investigation needs to be made of the variables especially resilience and competitiveness of seaports through the implementation of a "sea toll" program, especially regarding stakeholders in each area of the port authority. The different regulations and policies of the local government on each island will also affect the port system's development.

After consideration of the existing literature in this research area, we decided to comprehensively investigate and re-analyze the impact of the "sea toll" system development for the seaport system using AHP (Analytical Hierarchy Process) approaches. The expected output from AHP was a critical variable that could summarize all the information from stakeholders.

\section{The Impact of the "Sea Toll" Program on Seaport Resilience and Competitiveness}

One measure of resilience in a logistics system is the ability to overcome unexpected disruptions throughout the "sea toll" system [18]. There have been few, if any, studies of the development the "sea toll" system, especially in archipelago countries. However, some researchers have used quantitative approaches to measure resilience, including Henry and Ramirez-Marquez [19] who describe resilience as a time-dependent recovery ratio compared to maximum losses. Azevedo et al. [18] adopted an 
ecosilient index to measure the resilience of automotive supply chains in the upstream. This index uses the aggregation of a series of supply chain management practices related to the tenacious paradigm.

Pant et al. [20] introduced stochastic resistance measures for uncertainty and proposed models (including functions of vulnerability and recovery) based on the models for container terminals from the study of Henry and Ramirez-Marquez [19]. However, the analysis did not extend to the study of seaports, especially as part of a sea highway system. Research and discussions from qualitative aspects have also been carried out includes the conceptualization of "triangle resistance", considering factors such as resilience (initial impact on the system) and speed (speed of recovery) [21].

Previous studies have introduced several ways to improve resilience, especially for the conventional seaport system. According to Carvalho et al. [22], resilience needs to be designed. This study further proposed that collaboration, flexibility and visibility must be among the various seaport stakeholder bonds. Through the research of Lam and Bai [9], have recommended resilience measures by combining several variables from previous research. Measurement of resilience in their study is used to design supply chain resilience in conventional seaport systems. The parameters used in the current study are consistent with the most popular ones used by sea tolls involving many stakeholders at sea ports.

Several measures of resilience have been investigated in previous studies. Berle et al. [23] used contingency plans as one way to achieve redundancy. This was related to maintaining response capacity to disruptions in supply networks, for instance by providing capacity that exceeds requirements and before the point of need, and developing an emergency plan. Bottani and Rizzi [24] in their research carried out an increase in the accuracy of estimates for the level of inventory needed along the supply chain, thereby increasing supply chain visibility and responsiveness. Huang et al. [25] proposed that strategic alliances (running collaborative programs with partners) can reduce the level of uncertainty. Relationship management [23], defined as managing good supply chain relationships with customers and suppliers, has also been proposed.

Advanced IT systems (real-time search capabilities), such as enterprise resource planning (ERP), play an important role in information flow and increase SC flexibility [25]. Finally, Büyüközkan and Cifci [26] identified the management and supervision process as an organization, which takes supervision activities to ensure that suppliers, partners and their employees perform as expected. In addition, regular supervision needs to be done to reduce the risk of technical problems.

Measuring port competitiveness has also changed along with changes in their dynamic and complex business environment. Jeevan et al. [10] focuses on inland components (such as dry ports) that exist in port systems, which are one of the important components to improve container port performance, in particular. Because of the importance of dry port and container port relationships, their research divided the main components of competitiveness and land supporting components for dry ports.

In our study, we used five main parameters of the port's competitiveness based on Jeevan et al. [10]: seaport performance enhancements, capacity enhancements, improvements in port proximity, increases in service variations for seaports, and increases in the port's trade volume.

The involvement of dry ports in container port systems have improved container port performance by: increasing the frequency of vessel calls [27], improving overall reliability [28], improving port efficiency [29], reducing costs [30] and increasing dock productivity [31].

Increasing port capacity (for instance by providing space and facilities to perform several port functions on land), reduces congestion and obstacles to further expansion. As a result, the port gains additional space and facilities for its operations [32].

Increasing the proximity of inland ports to the seaport is important because dry ports act as an extension of the seaport and support the main seaport activities. This can help increase the access of the seaport to the interior through transportation networks [33], increasing accessibility to both ports and inland areas [34], and increasing port expansion in the sea [20,35].

Increased variation in services for ports allows port authorities and the government to flexibly provide additional services to ports that can benefit port clients [30]. With the performance of dry ports 
to act as a multifunctional logistics center helps the seaport operations comprehensively to enhance sustainable growth and maintain port competitiveness optimally [36].

Increasing the volume of port trade relies on the ports having additional capacity to achieve their goals. The contribution of dry port's to the port container trade can be measured by the level of container loading and unloading processes to and from the seaports or the volume of container transshipment produced by dry ports [37].

In our study, only these five measures of competitiveness were used because the assessment not only focused on the impact of container ports but on all aspects of the ports incorporated in the "sea toll" program. Inland components were included in the overall program section.

Based on port productivity data in Indonesia, for example in the port of Tanjung Priok (which has the largest percentage of domestic commodity loads of the five main ports), the highest productivity level (38.14\% for 2013-2014) was recorded in dry ports (compared to other commodities outside of the container port) [15]. Because of this domination by dry port services, which are part of the "sea toll" system, we assumed that the five competitiveness measures, together with other supporting variables, could be used to analyze the impacts of the "sea toll".

We combined our resilience measures with our port competitiveness measures [10] to determine the impact of the implementation of the "sea toll" program (see Table 2).

Table 2. Seaport competitiveness.

\begin{tabular}{ccc}
\hline Seaport Competitiveness & \multicolumn{1}{c}{ Components Influenced by Dry Ports } & Reference \\
\cline { 2 - 3 } Enhancement in seaport \\
performance & Ship calling frequency & {$[27,38]$} \\
\cline { 2 - 3 } & Reliability & {$[28,31,38-41]$} \\
\cline { 2 - 3 } & Efficiency & {$[29,33,38,40-43]$} \\
\hline \multirow{2}{*}{$\begin{array}{c}\text { Enhancement in seaport capacity } \\
\text { Improvement in seaport } \\
\text { hinterland proximity }\end{array}$} & Certh productivity & {$[30,44]$} \\
\cline { 2 - 3 } & Additional space for seaports & {$[32,40,45]$} \\
\cline { 2 - 3 } & Additional facilities to seaports & {$[30,46,49-51]$} \\
\hline Increase in service variations & Hinterland transport networks & {$[29,30,33,52-55]$} \\
\hline for seaports & Hinterland extension & {$[35,40,44,56-59]$} \\
\cline { 2 - 3 } & Supplementary services for seaports & {$[38,60-62]$} \\
\hline \multirow{2}{*}{\begin{tabular}{c} 
Increase in seaport trade volume \\
\cline { 2 - 3 }
\end{tabular}} & Continuity in container flow & {$[30,40,63-66]$} \\
\cline { 2 - 3 } & Transshipment containers & {$[30,31,35,41,72,74-77]$} \\
\hline
\end{tabular}

Source: Compiled from different sources.

Each sub-variable listed in the table, has been summarized and analyzed in detail by Jeevan et al. [10]. However, in this study we only use the main component as a general definition of the competitiveness of sea ports. While some sub-variables which are supporting variables of the main component are used as input for further development of the main components of port competitiveness.

\section{Research Methodology}

To analyze the impact of the "sea toll" program on port resilience and competitiveness, we conducted an online questionnaire survey with ten expert representatives from each stakeholder: the port authority, local government, shipping and logistics companies, and commodities companies, see Table 3. Online surveys were conducted between January and March 2019. 
Table 3. Respondent data for questionnaire distribution.

\begin{tabular}{cccc}
\hline No & Stakeholders & Company/Organization & Respondent \\
\hline 1 & Shipping/Logistics Companies & $5-10$ shipping companies & 10 expert officer \\
2 & Commodities Company & $5-10$ commodities companies & 10 expert officer \\
3 & Government & Representative of Ministry and Local Government & 10 expert officer \\
4 & Port Authority & Pelindo and Terminal Teluk Lamong & 10 expert officer \\
\hline
\end{tabular}

Survey questions were designed to explore the impact of the "sea toll" on port resilience and competitiveness. No open questions were used. In distributing the questionnaire, we determined the same quantity and parameters for representatives of each seaport stakeholder. This is intended to maintain the validity and balance of the roles of each stakeholder. Each respondent has at least 5 years working experience in his field, and understands the port management system and distribution pattern in the maritime sector especially sea toll issue.

The results of the survey were analyzed using the analytical hierarchy process (AHP) technique. AHP was first introduced by Thomas L. Saaty [78]. It can be used when decision makers have difficulty in determining the weights of various factors, as it allows them to be evaluated accurately.

A particularly interesting development was the use of fuzzy AHP within the maritime sector [79]. They study found that ports played a significant role in the economic development of a country. However, there were many problems with environmental pollution in the development and operations of a port. Thus, green concepts have emerged as a solution. The results of the empirical studies indicated that the five main priority attributes of green port operations are handling of hazardous waste, air pollution, water pollution, environmentally benign harbors, and the maintenance of habitat quality.

Based on these results, the fuzzy analytical hierarchy process (FAHP) model is one of the best references for port organizations to establish "environmentally friendly" port operations. Chen et al. [80] in their study modified the method related to analytical hierarchy process (AHP) and Dempster-Shafer evidence theory (D-S theory) is proposed for evaluating the impact of transport measures on city sustainability. AHP is adapted to determine the weight of sustainability criteria while D-S theory is used for data fusion of the sustainability assessment. With a modified AHP method, this technique has excellent performance in sensitivity analysis. However, there has been no research that uses this model and incorporates the interests of each stakeholder in each island region, and which is also related to a "sea toll" program case.

There are four stages of the AHP procedure [79], they are as follows:

1. Determining a hierarchical system by dissolving the problem into the hierarchy of interrelated variable.

2. Determining and calculating input data consisting of pairwise comparison matrices to find the comparative weights among the decision element's attributes.

3. Analyzing the assessment and estimating its relative weight.

4. Determining the composite relative weights of the decision elements to arrive at a series of assessments for alternative or decision strategies.

The respondents completed the questionnaire by simply comparing the importance level of each aspect by considering the following aspects as shown in each pairing table. The result of the comparison was then articulated into scales expressed in numbers. The comparison of each aspect should be done in a logical and consistent manner. Here is an example of the process of filling each selection of sub variables of each part of the main variable. Put a check mark $(\boldsymbol{V})$ on the scale column according to your opinion.

As shown in Figure 5, if we put $(\boldsymbol{V})$ mark on a scale (7:1) in the left column, the left-hand criterion in this example of contingency plan is more important than the right-hand one in this example of forecast accuracy. In contrast, if we put $(\boldsymbol{V})$ mark on scale (1:7) in the right column, the right-hand criterion of strategic alliance is more important than left-hand forecast accuracy criterion. 

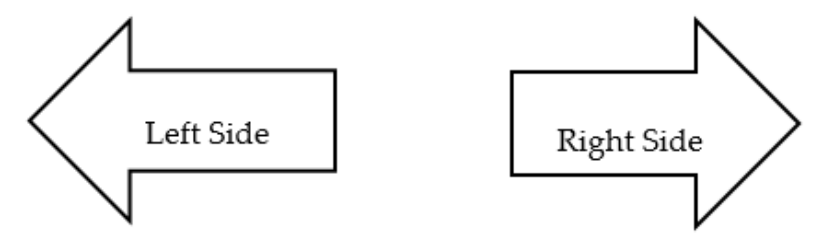

\begin{tabular}{|c|l|l|l|l|l|l|l|l|l|l|}
\hline Sub Variable & $9: 1$ & $7: 1$ & $5: 1$ & $3: 1$ & $1: 1$ & $1: 3$ & $1: 5$ & $1: 7$ & $1: 9$ & \multicolumn{1}{|c|}{ Sub Variable } \\
\hline \multirow{5}{*}{ Contingency plan } & & $\checkmark$ & & & & & & & & Forecast accuracy \\
\cline { 2 - 10 } & & & & & & & & & & Strategic alliance \\
\hline & & & & & & & & & & Advanced IT system \\
\hline & & & & & & & & & & Monitoring \\
\hline \multirow{5}{*}{ Forecast accuracy } & & & & & & & & $\checkmark$ & & Strategic alliance \\
\hline & & & & & & & & & & SC relationship \\
\hline
\end{tabular}

Figure 5. An example of filling in the analytical hierarchy process (AHP) score column.

The findings of our research using the AHP approach were more objective and comprehensive when compared to previous studies, especially those using a qualitative approach only, because respondents from each stakeholder filled out the questionnaire online, before the impact of the "sea toll" program on seaport resilience and competitiveness was investigated. This was particularly important for respondents from the local government, where each island region has different priority levels and interests.

\section{Data Analysis and Discussion}

We investigated the impact of the "sea toll" program on seaport resilience and competitiveness by considering the aspirations of stakeholders, such as the ministry of transportation of the Republic of Indonesia, local government, port authorities, commodities companies, and shipping/ logistics companies.

\subsection{The Impact of "Sea Toll" on Seaport Resilience}

Based on our explanations above, online questionnaires were distributed to expert representatives of each stakeholder, who understood the operational problems within the context of the "sea toll" program, and who had worked for at least five years in that institution. The goal was to obtain valid and reliable answers that we could analyze. In the stage of filling out the questionnaire, each respondent was asked to fill in the value of each comparison between variables, which later will be tabulated and analyzed using the SPSS software in accordance with the rules of the AHP method. After each individual respondent who has filled out an online questionnaire that distributed, then we will calculate each of the component values with SPSS software. Until all were collected from each respondent, then we took the average value of the whole to recalculate the overall consistency value.

The results of the questionnaire are shown in Table 4. The value for each variable was determined by taking the mean of all respondent's answers. The assessment criteria for each variable in the AHP method [78] were in Table 5. 
Table 4. Tabulation of data on the assessment of seaport resilience criteria by all respondents.

\begin{tabular}{cccccc}
\hline Seaport Resilience & $\begin{array}{c}\text { Contingency } \\
\text { Plan }\end{array}$ & $\begin{array}{c}\text { Forecast } \\
\text { Accuracy }\end{array}$ & $\begin{array}{c}\text { Strategic } \\
\text { Alliance }\end{array}$ & $\begin{array}{c}\text { SC Relationship } \\
\text { Management }\end{array}$ & $\begin{array}{c}\text { Advanced IT } \\
\text { System }\end{array}$ \\
\hline Contingency plan & 1 & 0.33 & 0.20 & 0.33 & 0.20 \\
Forecast accuracy & 3 & 1 & 0.50 & 3 & 2 \\
Strategic alliance & 5 & 2 & 1 & 3 & 3 \\
SC relationship management & 3 & 0.33 & 0.33 & 1 & 3 \\
Advanced IT system & 5 & 0.50 & 0.33 & 0.33 & 1 \\
Total & 17 & 4.17 & 2.37 & 7.67 & 9.20 \\
\hline
\end{tabular}

Source: Authors.

Table 5. The assessment criteria [78].

\begin{tabular}{cr}
\hline 1 & Both variables are equally important \\
\hline 3 & One variable is slightly more important than the other variable \\
\hline 5 & One variable is more important than the other variable \\
\hline 7 & One variable is much more important than any other variable \\
\hline $2,4,6,8$ were intermediate scores between the corresponding opinions given above
\end{tabular}

Next, we conducted a data normalization test for each variable, as shown in Table 6. In this stage, the calculation results in the initial data tabulation are processed to determine the priority vector value of each variable. Later through the priority vector value, it can be seen, which variable is dominant compared to other variables. From the results of the normalization test, the highest priority vector value was for the strategic alliance variable (0.38).

Table 6. Normalization test of port resilience criteria data.

\begin{tabular}{|c|c|c|c|c|c|c|c|}
\hline Seaport Resilience & $\begin{array}{l}\text { Contingency } \\
\text { Plan }\end{array}$ & $\begin{array}{l}\text { Forecast } \\
\text { Accuracy }\end{array}$ & $\begin{array}{l}\text { Strategic } \\
\text { Alliance }\end{array}$ & $\begin{array}{l}\text { SC Relationship } \\
\text { Management }\end{array}$ & $\begin{array}{l}\text { Advanced } \\
\text { IT System }\end{array}$ & Total & $\begin{array}{c}\text { Priority } \\
\text { Vector }\end{array}$ \\
\hline Contingency plan & 0.06 & 0.08 & 0.08 & 0.04 & 0.02 & 0.29 & 0.06 \\
\hline Strategic alliance & 0.29 & 0.48 & 0.42 & 0.39 & 0.33 & 1.91 & 0.38 \\
\hline SC relationship management & 0.18 & 0.08 & 0.14 & 0.13 & 0.33 & 0.85 & 0.17 \\
\hline Advanced IT system & 0.29 & 0.12 & 0.14 & 0.04 & 0.11 & 0.71 & 0.14 \\
\hline
\end{tabular}

We also tested the data consistency, see in Table 7. The highest matrix consistency value was for the strategic alliance variable $(2.10)$ and the value of consistency ratio (CR) was $0.099<0.1$. So we concluded that for seaport resilience, the strategic alliance variable had the greatest impact as a result of the "sea toll" program.

Table 7. Consistency test of port resilience criteria data.

\begin{tabular}{|c|c|c|c|c|c|c|}
\hline Seaport Resilience & $\begin{array}{l}\text { Contingency } \\
\text { Plan }\end{array}$ & $\begin{array}{l}\text { Forecast } \\
\text { Accuracy }\end{array}$ & $\begin{array}{l}\text { Strategic } \\
\text { Alliance }\end{array}$ & $\begin{array}{l}\text { SC Relationship } \\
\text { Management }\end{array}$ & $\begin{array}{l}\text { Advanced } \\
\text { IT System }\end{array}$ & Matrix \\
\hline Contingency plan & 1 & 0.33 & 0.20 & 0.33 & 0.2 & 0.30 \\
\hline Forecast accuracy & 3 & 1 & 0.5 & 3 & 2 & 1.41 \\
\hline Strategic alliance & 5 & 2 & 1 & 3 & 3 & 2.10 \\
\hline SC relationship management & 3 & 0.33 & 0.33 & 1 & 3 & 0.98 \\
\hline Advanced IT system & 5 & 0.50 & 0.33 & 0.33 & 1 & 0.74 \\
\hline Total & 17 & 4.17 & 2.37 & 7.67 & 9.20 & \\
\hline
\end{tabular}

Source: Authors. $\lambda=5.47, \mathrm{CI}=0.12, \mathrm{RI}=1.19, \mathrm{CR}=0.099$.

According to Huang et al. [25], strategic alliance is the process of establishing a collaborative program with partners or related stakeholders so as to reduce the uncertainty in the operation of 
the seaport system in a comprehensive manner. Thus, in the application of the "sea toll" program, stakeholders could be interpreted as having the view that the crucial impact, with regard to the existence of collaborative programs between institutions or stakeholders, was the reduction of uncertainty and an increase in the future resilience of the ports.

For Indonesia, as an archipelagic country with each local government having its own rules and policies for regulating port operations, it is very important to improve collaborative programs between the port areas. Synchronization of rules and policies will be needed to achieve optimal port resilience through Indonesia's "sea toll" program as shown in Figure 6.

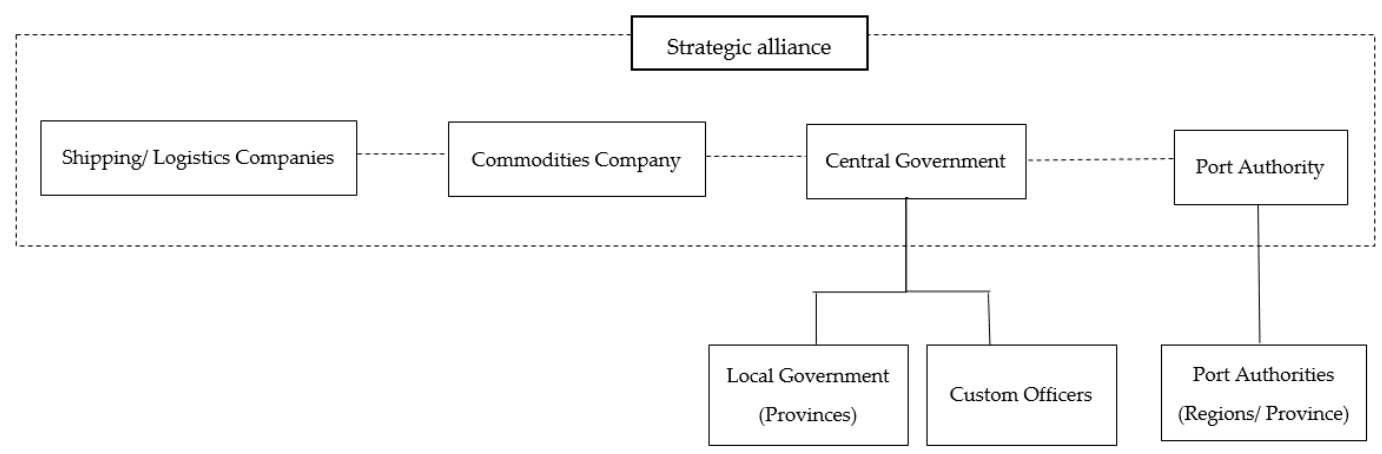

Figure 6. Strategic alliance framework.

\subsection{The Impact of "Sea Toll" on Seaport Competitiveness}

The questionnaire data for the impact of the "sea toll" on port competitiveness was analyzed in the same way as for the data on port's resilience (see Table 8).

Table 8. Tabulation of data on the assessment of seaport competitiveness criteria by all respondents.

\begin{tabular}{cccccc}
\hline Seaport Competitiveness & $\begin{array}{c}\text { Seaport } \\
\text { Performance }\end{array}$ & $\begin{array}{c}\text { Seaport } \\
\text { Capacity }\end{array}$ & $\begin{array}{c}\text { Seaport Hinterland } \\
\text { Proximity }\end{array}$ & $\begin{array}{c}\text { Service Variations } \\
\text { for Seaports }\end{array}$ & $\begin{array}{c}\text { Seaport Trade } \\
\text { Volume }\end{array}$ \\
\hline Seaport performance & 1 & 3 & 3 & 3 & 3 \\
Seaport capacity & 0.33 & 1 & 0.50 & 3 & 3 \\
Seaport hinterland proximity & 0.33 & 2 & 1 & 3 & 3 \\
Service variations for seaports & 0.33 & 0.33 & 0.33 & 0.33 & 1 \\
Seaport trade volume & 0.33 & 0.33 & 5.33 & 10.33 \\
Total & 2.33 & 6.67 & & \\
\hline
\end{tabular}

In this stage, similar to the previous stage in the aspect of resilience, the results of the calculation in the initial data tabulation are processed to determine the priority vector value of each variable. Later through the priority vector value, it can be seen, which variable is dominant compared to other variables. The results of the normalization test are shown in Table 9. The highest priority vector value was for seaport performance (4.93).

Table 9. Normalization test of port competitiveness criteria data.

\begin{tabular}{cccccccc}
\hline Seaport Competitiveness & $\begin{array}{c}\text { Seaport } \\
\text { Performance }\end{array}$ & $\begin{array}{c}\text { Seaport } \\
\text { Capacity }\end{array}$ & $\begin{array}{c}\text { Seaport } \\
\text { Hinterland } \\
\text { Proximity }\end{array}$ & $\begin{array}{c}\text { Service } \\
\text { variations } \\
\text { for Seaports }\end{array}$ & $\begin{array}{c}\text { Seaport } \\
\text { Trade } \\
\text { Volume }\end{array}$ & $\begin{array}{c}\text { Total } \\
\text { Priority } \\
\text { Vector }\end{array}$ \\
\hline Seaport performance & 0.43 & 0.45 & 0.56 & 0.29 & 0.25 & 1.98 & 4.93 \\
Seaport capacity & 0.14 & 0.15 & 0.09 & 0.29 & 0.25 & 0.93 & 2.30 \\
Seaport hinterland proximity & 0.14 & 0.30 & 0.19 & 0.29 & 0.17 & 1.09 & 2.70 \\
Service variations for seaports & 0.14 & 0.05 & 0.06 & 0.10 & 0.25 & 0.60 & 1.50 \\
Seaport trade volume & 0.14 & 0.05 & 0.09 & 0.03 & 0.08 & 0.40 & 1.00 \\
Total & 1 & 1 & 1 & 1 & 1 & 5 \\
\hline
\end{tabular}


A consistency test found that the highest matrix consistency value was obtained for the seaport performance variable (27.44) and the value of CR was $0.097<0.1$ (see Table 10). It was concluded that the seaport performance had the largest impact on the implementation of the "sea toll" program.

Table 10. Consistency test of port competitiveness criteria data.

\begin{tabular}{ccccccc}
\hline Seaport Competitiveness & $\begin{array}{c}\text { Seaport } \\
\text { Performance }\end{array}$ & $\begin{array}{c}\text { Seaport } \\
\text { Capacity }\end{array}$ & $\begin{array}{c}\text { Seaport } \\
\text { Hinterland } \\
\text { Proximity }\end{array}$ & $\begin{array}{c}\text { Service } \\
\text { Variations } \\
\text { for Seaports }\end{array}$ & $\begin{array}{c}\text { Seaport } \\
\text { Trade } \\
\text { Volume }\end{array}$ & Matrix \\
\hline Seaport performance & 1 & 3 & 3 & 3 & 3 & 27.44 \\
$\quad$ Seaport capacity & 0.33 & 1 & 0.50 & 3 & 3 & 12.79 \\
Seaport hinterland proximity & 0.33 & 2 & 1 & 3 & 2 & 15.45 \\
Service variations for seaports & 0.33 & 0.33 & 0.33 & 1 & 3 & 7.81 \\
Seaport trade volume & 0.33 & 0.33 & 0.50 & 0.33 & 1 & 5.26 \\
Total & 2.33 & 6.67 & 5.33 & 10.33 & 12.00 & \\
\hline
\end{tabular}

Source: Authors. $\lambda=5.46, \mathrm{CI}=0.12, \mathrm{RI}=1.19, \mathrm{CR}=0.097$.

According to Jeevan et al. [10], there are several inland components related to the performance of the seaport, such as ship calling frequency, reliability, efficiency, cost, and productivity. However, our study focused on the main components of seaport competitiveness. The inland component was a supporting variable in comprehensively defining the performance of the seaport as shown in Figure 7.

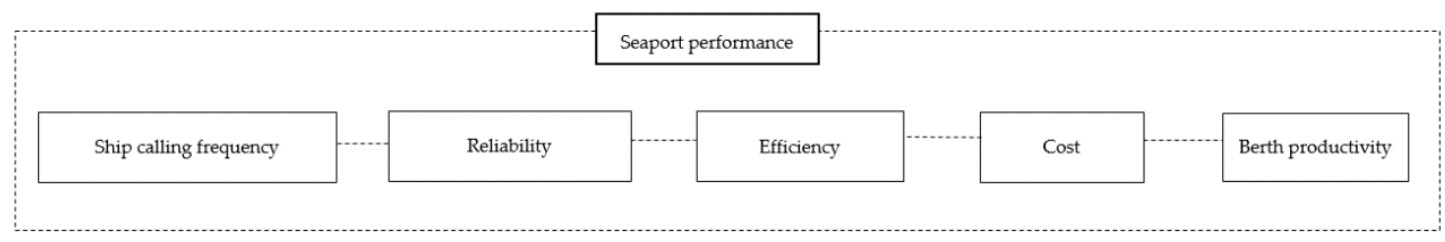

Figure 7. Seaport performance framework.

So, from the results of our investigation of the impact of the "sea toll" program, the seaport performance factor can be broadly defined regarding port operations of passenger ports, container ports, or even the dry port that is part of the "sea toll" program.

\section{Implication and Conclusions}

Overall our investigation showed that stakeholders considered that the "sea toll" program improved port resilience and competitiveness. Furthermore, we found that the largest influence on port resilience was from strategic alliances. This was interpreted as the establishment of a collaborative program with partners or related stakeholders that reduced uncertainty in the operations of the seaport system in a comprehensive manner. For port competitiveness, the largest impact was from the port performance which included other supporting elements such as ship calling frequency, reliability, efficiency, cost and productivity.

However, there were some weaknesses resulting from the implementation of the "sea toll" program: the use of sophisticated IT systems were not optimal for stakeholders, and the volume of inter-port trading also not optimal, which can be traced through data on container movement in each seaport, which will carry out the loading and unloading process.

In addition, it should be considered for the development of multi-stakeholder decision-making systems analysis that may still be lacking in the sea toll system for passenger and cruise services sector through the AHP approach and others in the future. More detailed and analytical investigations are needed, starting with the involvement of more diverse and varied stakeholder respondents.

These findings for the "sea toll" program and its impact on port resilience and competitiveness could be used to develop strategies to optimize port operations. They also provide a reference for 
policy makers in optimizing the "sea toll" program in their port development strategies to improve the efficiency and effectiveness of inter-island sea transportation services.

There were some limitations to this study, as it only dealt with the impact at the strategic level, so the technical aspects, especially regarding the classification of types of services for each seaport and operational technicalities, were not considered in detail within the "sea toll" program.

Future research should address the impact of the "sea toll" in more depth, with the addition of sub-variables at the analysis stage specifically related to port competitiveness, in order to provide an understanding of the impact at the operational or technical level and also related to the classification of port services due to the implementation of the "sea toll" program. Also accompanied by recommendations on strategies to improve port resilience and competitiveness based on the perspectives of each stakeholder will be very helpful in the future.

Author Contributions: Conceptualization, L.T.W.N.K.; methodology, L.T.W.N.K. and F.-S.T.; validation, L.T.W.N.K. and F.-S.T.; formal analysis, L.T.W.N.K.; investigation, L.T.W.N.K.; resources, L.T.W.N.K.; writing-original draft preparation, L.T.W.N.K.; writing-review and editing, L.T.W.N.K. and F.-S.T.; supervision, F.-S.T.

Funding: This research received no external funding.

Conflicts of Interest: The authors declare no conflict of interest.

\section{References}

1. World Population Review. (2019). Island Country 2019. Available online: http://worldpopulationreview. com/countries/island-countries/ (accessed on 17 April 2019).

2. Kementerian Perhubungan RI, (2013). Available online: http://www.dephub.go.id/ (accessed on 20 March 2017).

3. Pelindo Company. (2012). Annual Report. Available online: http://www.indonesiaport.co.id/sub/annualreport.html. (accessed on 20 March 2017).

4. World Bank. (2018). Indonesia Logistics Reform. Available online: http://documents.worldbank.org/curated/ en/ (accessed on 27 January 2019).

5. Liao, C.-N.; Kao, H.-P. An evaluation approach to logistics service using fuzzy theory, quality function development and goal programming. Comput. Ind. Eng. 2014, 68, 54-64. [CrossRef]

6. Liang, G.S.; Ding, J.F.; Wang, C.K. Applying fuzzy quality function deployment to prioritize solutions of knowledge management for an international port in Taiwan. Knowl. Based Syst. 2012, 33, 83-91. [CrossRef]

7. Dooms, M.; van der Lugt, L.; De Langen, P.W. International strategies of port authorities: The case of the Port of Rotterdam. Auth. Res. Trans. Bus. Manag. 2013, 8, 148-157. [CrossRef]

8. Lee, T.; Yeo, G.T.; Thai, V.V. Structural Analysis of Port Brand Equity Using Structural Equation Modeling. Asian J. Shipp. Logist. 2014, 30, 349-372. [CrossRef]

9. Lam, J.; Siu, L.; Bai, X. A quality function deployment approach to improve maritime supply chain resilience. Transp. Res. Part E: Logist. Transp. Rev. 2016, 92, 16-27. [CrossRef]

10. Jeevan, J.; Chen, S.L.; Cahoon, S. The impact of dry port operations on container seaports competitiveness. Marit. Econ. Logist. 2019, 46, 4-23. [CrossRef]

11. Ishizaka, A.; Labib, A. Review of the Main Developments in the Analytic Hierarchy Process. Expert Syst. Appl. 2011, 38, 14336-14345. [CrossRef]

12. Meidutè-Kavaliauskienè, I.; Aranskis, A.; Litvinenko, M. Consumer satisfaction with the quality of logistics services. Procedia Soc. Behav. Sci. 2014, 110, 330-340. [CrossRef]

13. Lino, R.J. The role of IPC in developing multimodal transportation in java. Available online: https://www. slideshare.net/IndonesiaInfrastructure/the-role-of-ipc-in-developing-multimodal-transportation-in-java (accessed on 31 March 2017).

14. America's Marine Highway Report to Congress. (2011). MARAD AMH Report to Congress. Available online: https://www.marad.dot.gov (accessed on 20 March 2017).

15. BPS RI. Seaports Data in Indonesia. Available online: https://www.bps.go.id/publication/2019/ (accessed on 27 January 2019).

16. Protopapas, A.; Kruse, C.J.; Olson, L.E.; Donelan, M.B.; Hutson, N. Marine Highway Transport of Toxic Inhalation Hazard Materials. Transp. Res. Record 2013, 2326, 1-7. [CrossRef] 
17. Fruth, M.; Teuteberg, F. Digitization in maritime logistics-What is there and what is missing? Cogent Bus. Manag. 2017, 4, 1411066. [CrossRef]

18. Azevedo, S.G.; Govindan, K.; Carvalho, H.; Cruz-Machado, V. Ecosilient Index to assess the greenness and resilience of the upstream automotive supply chain. J. Clean. Prod. 2013, 56, 131-146. [CrossRef]

19. Henry, D.; Ramirez-Marquez, J. Generic metrics and quantitative approaches for system resilience as a function of time. Reliab. Eng. Syst. Saf. 2012, 99, 114-122. [CrossRef]

20. Pant, R.; Barker, K.; Ramirez-Marquez, J.E.; Rocco, C.M. Stochastic measures of resilience and their application to container terminals. Comput. Ind. Eng. 2014, 70, 183-194. [CrossRef]

21. McDaniels, T.S.; Chang, D.C.; Mikawoz, J.; Longstaff, H. Fostering resilience to extreme events within infrastructure systems: Characterizing decision contexts for mitigation and adaptation. Glob. Environ. Chang. 2008, 18, 310-318. [CrossRef]

22. Carvalho, H.; Barroso, A.P.; Machado, V.H.; Azevedo, S.; Cruz-Machado, V. Supply chain redesign for resilience using simulation. Comput. Ind. Eng. 2012, 62, 329-341. [CrossRef]

23. Berle, Ø.; Rice, J.B.; Asbjørnslett, B. Failure modes in the maritime transportation system: a functional approach to throughput vulnerability. Marit. Policy Manag. 2011, 38, 605-632. [CrossRef]

24. Bottani, E.; Rizzi, A. Strategic management of logistics service: a fuzzy QFD approach. Int. J. Prod. Econ. 2006, 103, 585-599. [CrossRef]

25. Huang, S.T.; Bulut, E.; Duru, O.; Hwan, C.N.Y.; Yoshida, S. Service quality assessment in liner shipping industry: an empirical study on Asian shipping case. Int. J. Shipp. Transp. Logist. 2015, 7, 221-242. [CrossRef]

26. Büyüközkan, G.; Cifci, G. An integrated QFD framework with multiple formatted and incomplete preferences: a sustainable supply chain application. Appl. Soft Comput. 2013, 13, 3931-3941.

27. Langen, D.; Lugt, L.M. Government Structure of Port Authorities in the Netherlands: Devolution, Port Governance and Port Performance. J. Transp. Econ. 2007, 17, 109-137. [CrossRef]

28. Ballis, A.; Golias, J. Comparative Evaluation of Existing and Innovative Rail-Road Freight Transport Terminals. J. Transp. Res. Part A 2002, 36, 593-611. [CrossRef]

29. Ng, A.K.; Gujar, G.C. Government Policy, Efficiency and Competitiveness: The Case Study of Ports in India. J. Transp. Policy 2009, 16, 232-239. [CrossRef]

30. Roso, V.; Lumsden, K. A Review of Dry Ports. J. Marit. Econ. Logist. 2010, 12, 196-213. [CrossRef]

31. Beresford, A.; Petit, S.; Xu, Q.; Williams, S. A Study of Dry Port Development in China. J. Marit. Econ. Logist. 2012, 14, 73-98. [CrossRef]

32. Ruan, X.; Feng, X.; Pang, K. Development of Port Service Network in OBOR via Capacity Sharing: An Idea from Zhejiang Province in China. Marit. Policy Manag. 2017, 1-20. [CrossRef]

33. Jarzemskis, A.; Vailiauskas, V. Research on Dry Port Concept as Intermodal Node. J. Transp. Econ. 2007, 22, 207-213. [CrossRef]

34. Klink, H.A. Optimisation of land access to sea ports. In Proceedings of the Land Access to Sea Ports. European Conference of Ministers of Transport, Rotterdam, The Netherlands, 25-28 June 2007; pp. 10-17.

35. Ng, A.K.Y.; Cetin, B. Locational Characteristics of Dry Ports in Developing Economies: Some Lessons from Northern India. J. Reg. Stud. 2012, 46, 757-773. [CrossRef]

36. Heilig, L.; Voß, S. Inter-Terminal Transportation: An Annotated Bibliography and Research Agenda. Flex. Serv. Manuf. J. 2016, 28, 1-29. [CrossRef]

37. Vernimmen, B.; Dullaert, W.; Engelen, S. Schedule Unreliability in Liner Shipping: Origins and Consequences for the Hinterland Supply Chain. J. Marit. Econ. Logist. 2007, 9, 193-213. [CrossRef]

38. Roso, V. Factors Influencing Implementation of a Dry Port. Int. J. Phys. Distrib. Logist. Manag. 2008, 38, 782-798. [CrossRef]

39. Heaver, T. The Evolving Roles of Shipping Lines in International Logistics. J. Marit. Econ. 2001, 4, $210-230$. [CrossRef]

40. Roso, V.; Woxenius, J.; Lumsden, K. The Dry Port Concept: Connecting Container Seaports with the Hinterland. J. Transp. Geogr. 2009, 17, 338-345. [CrossRef]

41. Rodrigue, J.P.; Notteboom, T. The Terminalization of Supply Chains: Reassessing the Role of Terminals in Port-Hinterland Logistical Relationships. J. Marit. Policy Manag. 2009, 36, 165-183. [CrossRef]

42. Bichou, K.; Gray, R. A Critical Review of Conventional Terminology for Classifying Seaports. J. Transp. Res. Part A: Policy Pract. 2005, 39, 75-92. [CrossRef] 
43. Cetin, K.; Cerit, A.G. Organisational Effectiveness at Seaports: A System Approach. J. Marit. Policy Manag. 2010, 37, 195-219. [CrossRef]

44. Rodrigue, J.P.; Notteboom, T. Foreland-Based Regionalization: Integrating Intermediate Hubs with Port Hinterlands. Res. Transp. Econ. 2010, 27, 19-29. [CrossRef]

45. Padilha, P.; Ng, A.K. The Spatial Evolution of Dry Ports in Developing Economies. The Brazilian Experience. J. Marit. Econ. Logist. 2012, 14, 99-121. [CrossRef]

46. Frost, J.D. The Close Dry Port Concept and the Canadian Context. J. Marit. Econ. Logist. 2010, 10, $108-129$.

47. Lin, D.Y.; Huang, K.L. An Equilibrium-Based Network Model for International Container Flows. Marit. Policy Manag. 2017, 44, 1034-1055. [CrossRef]

48. Xing, W.; Liu, Q.; Chen, G. Pricing Strategies for Port Competition and Cooperation. Marit. Policy Manag. 2018, 45, 260-277. [CrossRef]

49. Visser, J.; Konings, R.; Pielage, B.J.; Wiegmans, B. A New Hinterland Transport Concept for the Port Rotterdam: Organisational or Technological Challenges? J. Transp. Res. 2009, 4, 201-216.

50. UNESCAP. The Development of Dry Ports along the Asian Highway and Trans-Asian Railway Networks. United Nation Economic and Social Commission for Asia and the Pacific. United Nation; UNESCAP: Bangkok, Thailand, 2010.

51. Haralambides, H.E.; Gujar, G. Dry Port Efficieny and Container Security. In Proceedings of the IAME, Santiago, Chile, 26-28 October 2016.

52. Migliardi, A.; Beretta, E.; Vacche, A.D. The Port of Genoa: A Gateway for the North West of Italy. In Proceedings of the IAME, Marseille, France, 3-5 July 2013.

53. Notteboom, T.; Rodrigue, J.P. Port Regionalization: Towards a New Phase in Port Development. J. Marit. Policy Manag. 2005, 32, 297-313. [CrossRef]

54. Wisetjindawat, W.; Sano, K.; Matsumoto, S.; Raothanachonkun, P. Micro-Simulation Model for Modeling Freight Agents Interactions in Urban Freight Movement. In Proceedings of the 86th Annual Meeting of the Transportation Research Board, Washington, DC, USA, 21-25 January 2007.

55. Alemán, A.; Serebrisky, T.; de León, O.P. Port Competition in Latin America and the Caribbean: The Role of Concessions and Competition Policy. Marit. Policy Manag. 2017, 1-19.

56. Roso, V.; Russell, D.; Ruamsook, K.; Stefansson, G. Seaport-Inland Port Dyad Dynamics: An Investigation of Service Provisions and Intermodal Transportation Linkages. World Rev. Intermodal Transp. Res. 2015, 5, 263-280. [CrossRef]

57. Woxenius, J.; Roso, V.; Lumsden, K. The Dry Port Concept-Connecting Seaports with Their Hinterland by Rail. In Proceedings of the ICLSP Conference Proceedings, Dalian, Department of Transportation and Logistics Chalmers University of Technology, Dalian, China, 22-26 September 2004; pp. 305-319.

58. Rodrigue, J.P. Transportation Modes. In The Geography of Transport System, 1st ed.; Taylor and Francis Group: New York, NY, USA, 2006; pp. 212-240.

59. McCalla, R. Factors Influencing the Landward Movement of Containers: The Cases of Halifax and Vancouver. In Proceedings of the International Workshop on Ports, China: Cities and Global Supply Chains, Hong Kong, China, 12-14 December 2005; pp. 121-137.

60. Tongzon, J. Port Choice and Freight Forwarders. Transp. Res. Part E: Logist. Transp. Rev. 2009, 45, $186-195$. [CrossRef]

61. Crainic, T.G.; Dell'olmo, P.; Ricciardi, N.; Sgalambro, A. Modeling dry port based freight distribution planning. Transp. Res. Part C: Emerg. Technol. 2015, 55, 518-534. [CrossRef]

62. Wan, Y.; Zhang, A.; Li, K.X. Port Competition with Accessibility and Congestion: A Theoretical Framework and Literature Review on Empirical Studies. Marit. Policy Manag. 2018, 45, 239-259. [CrossRef]

63. UNESCAP; KMI. Logistic Sector Development: Planning Models for Enterprises and Logistic Clusters. Thailand: New York and Korean Maritime Institute. United Nations; UNESCAP: Bangkok, Thailand, 2007.

64. Cruijssen, F.; Cools, M.; Dullaert, W. Horizontal Cooperation in Logistics: Opportunities and Impediments. J. Transp. Res. Part E 2007, 43, 129-142. [CrossRef]

65. Andersson, D.; Roso, V. Developing Dry Ports through the Use of Value-Added Services; Springer International Publishing: Cham, Switzerland, 2015.

66. Notteboom, T.; Rodrigue, J. Inland Terminals within North American and European Supply Chains; United Nations: Transport and Communication Bulletin for Asia and the Pacific: Bangkok, Thailand, 2009; pp. 98-115. 
67. Paixao, A.C.; Marlow, P.B. Fourth Generation Ports: A Question of Agility? Int. J. Phys. Distrib. Logist. Manag. 2003, 33, 355-376. [CrossRef]

68. Verhoeven, P. A Review of Port Authority Functions: Towards a Renaissance? Marit. Policy Manag. 2010, 37, 247-270. [CrossRef]

69. FDT. Feasibility Study on the Network Operation of Hinterland Hubs (Dry Port Concept) to Improve and Modernize Ports' Connections to the Hinterland and to Improve Networking; In Project - Integrating Logistics Centre Networks in the Baltic Sea Region, The Centre of Maritime Studies (CMS) of the University of Turku: Turku, Finland, 2007; pp. 21-64.

70. Notteboom, T.E.; Winkelmans, W. Structural Changes in Logistics: How Will Port Authorities Face the Challenge? Marit. Policy Manag. 2001, 28,71-89. [CrossRef]

71. Allen, J.; Thorne, G.; Browne, M. Good Practice Guide on Urban Freight Transport. BESTUFS.NET: Rijswijk, The Netherlands. 2007. Available online: https://westminsterresearch.westminster.ac.uk/item/91w49/bestufsgood-practice-guide-on-urban-freight-transport (accessed on 18 August 2019).

72. Notteboom, T. The Time Factor in Liner Shipping Services. Marit. Econ. Logist. 2006, 8, 19-39. [CrossRef]

73. Werikhe, G.W.; Jin, Z. A Comparative Study of Dry Ports in East Africa and China. Dev. Ctry. Stud. 2015, 5, 7-17.

74. Lirn, T.C.; Thanopoulou, H.A.; Beynon, M.J.; Beresford, A.K.C. An Application of AHP on Transshipment Port Selection: A Global Perspective. J. Marit. Econ. Logist. 2004, 6, 70-91. [CrossRef]

75. Acciaro, M.; Mckinnon, A. Efficient Hinterland Transport Infrastructure and Services for Large Container Ports; International Transport Forum European Conference of Ministers of Transport; Port Investment and Container Shipping Markets Roundtable: Hamburg, Germany, 2013; pp. 18-25.

76. Rodrigue, J.P.; Notteboom, T. Dry Ports in European and North American Intermodal Rail Systems: Two of a Kind? Res. Transp. Bus. Manag. 2012, 5, 4-15. [CrossRef]

77. Henttu, V.; Multaharju, S. Transshipment Costs of Intermodal Transport in Finnish Context; Tutkimusraportti Research Report Finland: Faculty of Technology Management, Department of Industrial Management; Lappeenranta University of Technology: Lappeenranta, Findland, 2011; pp. 19-32.

78. Saaty, T.L. The Analytic Hierarchy Process; New York: McGraw Hill. International, Translated to Russian, Portuguese, and Chinese, Revised editions, Paperback (1996, 2000); RWS Publications: Pittsburgh, PA, USA, 1980.

79. Chiu, R.H.; Lin, L.; Ting, S. Evaluation of Green Port Factors and Performance: A Fuzzy AHP Analysis. Math. Probl. Eng. 2014, 802976, 12. [CrossRef]

80. Chen, L.; Deng, X. A Modified Method for Evaluating Sustainable Transport Solutions Based on AHP and Dempster-Shafer Evidence Theory. Appl. Sci. 2018, 8, 563. [CrossRef] 